\title{
CIVIL JUSTICE IN INDIA
}

\author{
KRISHNA AGRAWAL, \\ University of Rajasthan (Jaipur, India) \\ NEHA DIXIT, \\ University of Rajasthan (Jaipur, India)
}

DOI: 10.21684/2412-2343-2016-3-4-71-93

In India the concept of civil justice is not new. It has existed since time immemorial. A large number of related provisions are found in Manu, who compiled the then existing justice system in India of thousands of years ago in his fourteen-volume work titled Manava Dharma Shastra. The concept of justice is also found in detail in the Vedas, which are from a very ancient time. In both these scriptures the rule of law was adequately provided. Today, however, the Indian civil justice system resembles its common law counterparts. It features a coordinated, pyramid structure of judicial authority, emphasizing formal procedural justice dominated by litigants of equal status engaged in adversarial processes, and provides binding, win-lose remedies.

Keywords: civil justice in India; courts and judges; jurisdictions; evidence.

Recommended citation: Krishna Agrawal \& Neha Dixit, Civil Justice in India, 3(4) BRICS Law Journal 71-93 (2016).

\section{Table of Contents}

\section{Historical Background of the Judicial System in India}

1.1. Civil Justice System during the Ancient Period (until the Muslim Period)

1.2. Civil Justice System during the Muslim Period

\subsection{Advent of Mughals in India}

1.4. Civil Justice System during the British Period (under the East India Company)

1.5. Acquisition of the Zamindari System in Bengal in 1765 


\subsection{Law Applied by the Courts during the British Period}

1.7. Law in the Mofussil

2. Courts and Judges Today

3. Scope of Civil Procedure

4. Structure (Stages) of Civil Procedure

5. Fundamental Principles

6. Access to Justice

7. Forms of Action

8. Jurisdiction

9. Role of Judges

10. Evidence

11. Summary Proceedings

12. Appellate Proceedings

13. Class Actions

14. Costs and Funding

15. Enforcement of Proceedings

16. Arbitration and ADR

17. Role of Academia

18. Statistics

19. Comparative Observations

20. Cultural Observations

21. International Matters and BRICS Cooperation in Civil Procedure Perspectives

\section{Conclusion}

\section{Historical Background of the Judicial System in India}

\subsection{Civil Justice System during the Ancient Period (until the Muslim Period)}

The history of the Indian judicial system goes back to the ancient time when Manu and Brihaspati gave Indians Dharma Shastras, Narada the Smritis, and Kautilya the Artshastra. A study of these memorable books would reveal that in ancient India there was a fairly well-developed and sophisticated system of administration of justice. In broad outline, there is considerable similarity between the system now in force and civil judicial proceedings in ancient India. During the ancient period legal procedure, including that of case filing, was called vyavahara. The equivalent of modern "complaint" was called purvapaksha, and that of "written statement" uttar (or "reply" in modern civil procedure). The trial was called kriya and verdict nirnaya. The profession of lawyers, or advocates, was unknown during this period. Trial by jury and trial by ordeal were the two types of trials that existed then. The ancient Indian and constitutional system had established a duty-based society. It postulated that everybody from the king to the lowest of society was bound to fulfil his or her duty towards society. This was true for the 
whole of India, notwithstanding the existence of larger and smaller kingdoms, and that the supremacy of dharma (law) over the kings as declared in the authoritative texts was respected in letter and in spirit. Thus there were no absolute monarchies. The modern concept of "the King can do no wrong" did not apply. The king was equally bound by the same law. He was equally liable for civil and criminal actions.' The king's court was the highest court, next to which came the court of the chief justice (pradvivaka). The king's court was the highest court of appeal as well as an original court in cases of vital importance to the state. In the king's court the king was advised by learned people such as Brahmins, the ministers, the Chief Justice, etc. The appeals system was practised and the king was the highest body of appeal. One significant feature of the ancient Indian legal system was the absence of lawyers. Another notable feature was that a bench of two or more judges was always preferred to administer justice rather than a single individual being the sole administrator of justice. This form of justice continued in several Hindu princely states even before the Independence of India.

\subsection{Civil Justice System during the Muslim Period}

The advent of Muslim rule in India began in the $12^{\text {th }}$ century when Muhammad Gouri attacked India and occupied the throne at Delhi. In the beginning, the Muslim rulers were not very much interested in establishing a civil justice system in India. They continued to administer civil justice to Hindus in consultation with Hindu advisors who were considered specialists in Hindu law. The Tughlaq period saw the compilation of the code of civil procedure, which was called Fiqha-e-Feroze Shahi. The code prescribed details of the procedure and the law in several matters. It was written in Arabic and was translated into Persian under the orders of Feroz Shah Tughlaq. The procedure laid down in this book was followed until the reign of Aurangzeb when it was replaced by Fatawa-i-Alamgiri written in 1670. According to Fatawa-i-Alamgiri, the Qazi first prayed and craved God's help in the administration of justice. He was assisted by Katib. The Qazi was obliged to see that the evidence was correctly recorded. The plaintiff was called the muddai and the defendant muddaa allaih. The complaint was called daawa, whereas the complaint in criminal cases was called Istaghasa. A party could have an agent as vakil or an attorney to represent his case.

\subsection{Advent of Mughals in India}

The advent of the rule of the Mughals was important so far as the civil justice system in India is concerned. The Mughals played a very significant role in the judicial system in India. They brought new changes to the judicial system and had a great impact in India. The Mughals first of all tried to establish a strong and well-organized government contributing to peace and order. Secondly, they also tried to establish a highly centralized form of government with extensive administrative machinery. The duties of a Muslim king in an Islamic state required him to rule in accordance with the

See Rama Jois, Seeds of Modern Public Law in Ancient Indian Jurisprudence 1-2 (Lucknow: Eastern Book Company, 1990). 
Quranic law and to enforce shariah in his kingdom. Under the Muslim king, the subjects were divided into two sections, believers and non-believers, and a duty was imposed on the king to see that believers lived as true Muslims and non-believers remained in the position allotted to them as Zimmis, a position which denied them equal status with Muslim subjects but guaranteed them security of life and property, and the continuance of their religion and religious practices under certain defined conditions. Therefore a Muslim king, besides performing the ordinary duties connected with his office, also had to uphold the dignity of his religion through defined channels and to rule according to Islamic law. The second aspect of the Islamic system which guaranteed peace and security of life and prosperity to non-believers included impartial justice, and this aspect of kingship was emphasized. One of the most important agencies in the administration of justice was the institution of Qazi. He held court and gave justice. However, in all cases the king was still above the law. The king's court was the highest appellate court in the empire, imparting civil and criminal justice.

\subsection{Civil Justice System during the British Period (under the East India Company)}

The advent of British rule in the beginning of the $17^{\text {th }}$ century ushered in a new era of civil justice in India. The Royal Charter of 1600 established the English East India Company in India. The charter effectively brought the people living there under the Company's control. The British located themselves in the presidencies of Calcutta, Madras (now Tamil Nadu) and Bombay. From 1661 to 1726 laws based on equity, justice and good conscience in conformity with the laws of England were followed. There was no codified law. On the request of the Company, the Charter of 1726 granted it special powers. Under this charter Mayor's Courts were established in the presidencies and these courts applied English law to the people living there. Later these courts were converted into the then Supreme Courts and later on renamed High Courts in different presidencies.

\subsection{Acquisition of the Zamindari System in Bengal in 1765}

In 1765 , the Company acquired Zamindari (collectors of revenue) from the rulers of Bengal Bihar and Orissa and as such it had to establish a parallel judicial system in the mofussil (i.e. areas, rural localities, outside the three presidencies mentioned earlier). Under its Plan of 1774, diwani adalats (civil courts) were established in each district. The areas of Bengal, Bihar and Orissa were divided into six districts. From Diwani Adalats appeals lay to Saddar Diwani Adalats. After the Revolution of 1861, High Courts were established at Bombay, Calcutta and Madras and all other Saddar Diwani Adalats and the Mayor's Courts established in 1726 were abolished. Later on High Courts were established at other big cities of India.

\subsection{Law Applied by the Courts during the British Period}

The following law was applied by the Supreme Courts in the three presidency cities: (i) common law as it prevailed in England in 1726; (ii) statute law that prevailed 
in England in 1726, including law subsequently enacted by Parliament; (iii) regulations made by the Governor General in Council prior to the Act of 1833 and also the Acts by the Governor General in Council under the Act of 1833; (iv) Hindu law and usages in respect of Hindus, and Muslim law and usages in respect of Muslims. So far as other communities, e.g., Christians, Parsees, Jews, etc., were concerned, English law in use was to apply to them.

\subsection{Law in the Mofussil}

According to the Plan of Warren Hastings of 1772, in suits regarding inheritance, marriage, caste and other religious usages and institutions, laws of the Quran, with respect to Muslims, and those of the Shaster, with respect to Hindus, were invariably to be adhered to. Maulvies or Brahmins were, respectively, appointed to expound the law. So far as other communities, e.g., Christians, Parsees and Jews, etc., were concerned, their disputes were decided according to equity, justice and good conscience. For Anglo-Indians, the law of England was applied. This situation was changed after the Charter Acts of 1833 and 1853 of the British Parliament. Subsequent to these Acts, a process of compilation and codification began. Law Commissions were appointed in the matter. These Commissions were always assisted by Indians in the formulation of the codes.

\section{Courts and Judges Today}

There is a network of judicial courts in India. The Supreme Court is the highest independent court. The judges of the Court are appointed by the President of India on the recommendation of the Collegium of the five most senior judges of the Supreme Court. The Supreme Court has (i) original, (ii) appellate and (iii) advisory jurisdiction. Under original jurisdiction, the Supreme Court decides disputes "between the Government of India and one or more [s]tates or between the Government of India and any [s]tate or [s]tates on one side and one or more [s]tates on the other or between two or more [s]tates." ${ }^{\prime 2}$ The Court also decides the disputes relating to the election of the President and Vice President. It has concurrent jurisdiction with the High Courts in the enforcement of fundamental rights. The Supreme Court has exclusive jurisdiction to decide only those disputes between states which arise in the context of the Constitution and the federal structure as established under it. As regards appellate jurisdiction, appeals lie to the Court in (i) constitutional matters; (ii) civil matters; (iii) criminal matters from a judgment of a High Court where it has granted a certificate for making such appeal. However, under Art. 136 of the Constitution an individual can seek the special leave to appeal without such a certificate. Under Art. 143(1), the President of India may seek advice from the Supreme Court on any

\footnotetext{
Supreme Court of India, Jurisdiction of the Supreme Court (Dec. 20, 2016), available at http://www. supremecourtofindia.nic.in.
} 
question of law or fact which in his opinion is of such a nature and public importance that it is expedient to obtain the Court's opinion.

Every state or two or more states have High Courts which have the highest judicial power in the state. The judges of the High Courts are appointed by the President of India on the recommendation of the Collegium of the Supreme Court. The High Courts have the following powers: (i) superintend the subordinate courts and tribunals within its jurisdiction; (ii) hear matters relating to fundamental rights and other rights; (iii) remove a case from a subordinate court regarding interpretation of the Constitution; (iv) hear appeals in civil and criminal matters. In addition to the High Court in a state, there is a network of subordinate courts deciding civil and criminal cases.

\section{Scope of Civil Procedure}

Section 10 of the Code of Civil Procedure, 1908 (CPC) provides that the courts shall, except for the provisions otherwise provided, have jurisdiction to try all suits of a civil nature excepting suits of which their cognizance is either expressly or implicitly barred. A suit is of a civil nature if the principal question in the suit relates to the determination of a civil right. There are certain suits which are barred by specific Acts of the legislature or on the grounds of public policy. For example, there are the Acts dealing with matters relating to cooperative societies, labour disputes, transport matters, etc. Similarly there are suits which are barred on the grounds of public policy, e.g., renting a house for the purpose of prostitution, enforcement of an agreement to suppress criminal prosecution, suits to enforce an agreement to suppress an unlawful agreement, etc.

\section{Structure (Stages) of Civil Procedure}

There is a detailed procedure laid down for filing a civil case. If the procedure is not followed, then the registry has a right to dismiss the suit. First, the complaint, along with vakalatnama (a kind of power of attorney) and any necessary court fee, is filed. After the receipt of the complaint, notices are issued to the defendants for reply. The defendants submit their reply, which is known as the written statement. Afterwards, the plaintiff submits a rejoinder to the written statement. The court, after examining the complaint, the written statement and the rejoinder, determines the points of contention, which is known as framing of the issues. Thereafter, both parties submit documents and a list of witnesses in order to substantiate their contentions. Subsequently, witnesses are examined and oral arguments between the advocates of the parties take place. Thereafter, judgment is pronounced.

When an order is passed against a party to the suit, it is not that the party has no further remedy. The party can further initiate proceedings by way of appeal, revision or review.

Appeal. An appeal is filed in the form prescribed, signed by the appellant, along with a true certified copy of the order. The appeal should contain the grounds of 
objection under distinct headings, and such grounds will be numbered consecutively. If the appeal is against a decree for payment of money, the court may require the appellant to deposit the disputed amount or furnish other security. A ground/ objection which has not been mentioned in the appeal cannot be taken up for arguments without the permission of the court. Similarly, any point or act which was not taken up by the appellant in lower court cannot be taken up in appeal except with the permission of the appellate court. An appeal before a High Court can be filed before the High Court within 90 days and before other courts within 30 days.

Revision and Review. In revision, a High Court can call for the record of any case which has been decided by any subordinate court in which no appeal lies thereto, if such subordinate court appears to (i) have exercised a jurisdiction not bestowed on it by law or (ii) have failed to exercise a jurisdiction so vested or (iii) have acted in the exercise of its jurisdiction illegally or with material irregularity. A review of the judgment is made by the same court that decided the case. Any person considering himself aggrieved by (a) a decree or order from which even though appeal is allowed no appeal has been referred or (b) a decree or order from which no appeal is allowed may apply for a review of the judgment to the court that passed the decree or issued the order, either on the discovery by the applicant of new and important material or evidence which, after the exercise of due diligence, was not within his knowledge or could not be produced at the time the decree was passed or the order issued, or on account of some mistake or error apparent on the face of the record, or for any other sufficient reason.

\section{Fundamental Principles}

The fundamental principle of the Code of Civil Procedure is to consolidate and amend the laws relating to the procedure of the courts of civil jurisdiction. The Code of Civil Procedure is deemed to be one of the primary procedural laws in India which is involved neither in taking away rights nor in engendering them, it is solely involved in regulating court procedure. It is designed to facilitate justice and further its ends. The Code has been divided into two parts, viz., (1) substantive law from section 1 to section 158, and (2) procedural law in 51 Orders. The first part contains provisions of a substantive nature that lay down the general principles and create jurisdiction, while the second part contains provisions that relate to procedure and indicate the mode in which jurisdiction created by the body of the Code has to be exercised. The first part is fundamental and it cannot be altered except by Parliament, whereas the High Courts are empowered to annul, alter or add to all or any of the said rules embodied in the second part, provided such annulment, alteration or addition is not inconsistent with the provisions of the first part.

The Code of Civil Procedure acknowledges the powers of, along with the limitations on, the courts, but there are some powers that are vested in the courts but not prescribed in the Code, and they are the inherent powers. The inherent powers of the court are in addition to the powers specifically conferred by the Code on the court. 
They are complimentary to those powers. The court is free to exercise them for the ends of justice or to prevent the abuse of the processes of the court. The reason is obvious. The powers of the court are not comprehensively set down for the simple reason that the legislature is incapable of contemplating all the possible situations that might arise in future litigations. Inherent powers come to the rescue in such unforeseen circumstances. They can be exercised ex debito justitiae in the absence of provisions in the Code. But they need to be exercised with due care and not arbitrarily.

\section{Access to Justice}

From the very beginnings of Indian society people had access to justice. During the Hindu period and also the Muslim period even the poorest could directly gain access to justice. Under British rule, however, it was not so. Access to justice became very expensive because of heavy court fees, high fees charged by advocates and other expenses. For ordinary people this amounted to the virtual denial of access to justice. Against this backdrop, provisions for indigent persons were made in Order XXXIII of the Code of Civil Procedure stipulating that a person who does not have property worth 1,000 rupees (Rs.1,000) can file suit without payment of the court fee.

Legal Aid. Art. 39A of the Indian Constitution enjoins the government to provide legal aid to poor persons. The legal aid movement received a boost with the setting up of the Committee for Implementation of Legal Aid Schemes (CILAS) in 1980. CILAS evolved a model scheme for the legal aid programme which includes:

(i) the promotion of legal literacy and creation of legal awareness among weaker sections of the country;

(ii) organization of legal aid camps;

(iii) training of paralegals for the purpose of providing support to the legal aid programmes;

(iv) setting up legal aid clinics in universities and law colleges;

(v) public interest litigation;

(vi) holding of Lok Adalat (people's court);

(vii) enforcement of and support to voluntary organizations and social action groups by the state in operating legal aid programmes.

At present, legal aid programmes are being implemented throughout the country by the states and advisory boards which have been set up in all the states.

\section{Forms of Actions}

There are various levels of the judiciary in India and there are different types of courts, each with powers that vary depending on the tier and jurisdiction bestowed on them. This creates a strict hierarchy of importance of the courts, and, in line with the order of the courts in which they sit, for the judges, beginning at the top with the Supreme Court of India, followed by the High Courts of the respective states, 
the District Courts, and civil judges and magistrates, and civil judges of the Senior and Junior Divisions at the bottom. Courts hear criminal and civil cases, including disputes between individuals and the government. The judiciary is independent of the executive and legislative branches of government according to the Constitution of India. There are different writs in the nature of habeas corpus, mandamus, prohibition, certiorari, quo warranto, etc., by which the Supreme Court and High Courts deal with violations of fundamental rights. The forms of action govern the pleadings under the Code of Civil Procedure. The different forms of action include recovery of debt, deciding cases of contract and matrimonial disputes, among others. A litigant can sue for money due on an account, make a demand for a certain sum of money or demand a specific item of personal property. The action of trespass is common because a form allowing the claim that force had been wrongfully used could cover a wide variety of injuries. Similarly, every decree for payment of money may be executed even by ordering detention in civil prison of the judgment debtor or by the attachment and sale of his property, or by both. It may also be executed by arrest and detention in prison, not exceeding the period of three months, of civil imprisonment in cases where the sum of money exceeds Rs.5,000. Where a decree is for the payment of a sum of money exceeding Rs.2,000, but not exceeding Rs.5,000, the period for civil imprisonment will not exceed six weeks. In cases where the decree is for specific movable property, it may be executed by seizure of that property and delivery thereof to the party to whom it has been adjudged or by civil imprisonment of the judgment debtor or by the attachment of his property for a period of three months, or by both. The enforcement of restitution of conjugal rights can be made only by the attachment of property of the judgment debtor, where the debtor refused to obey the decree. Another form of action is injunction, where the party is prohibited from performing an act and if the party disobeys the injunction, the remedy for the plaintiff is the detention of the defendant in civil prison, or by attachment of his property, or by both. Fundamental rights are given to citizens under Part III of the Constitution; Arts. 32 and 226 provide the right to constitutional remedy. The enforceability of rights depends on capacity, jurisdiction and defences available, including immunities.

\section{Jurisdiction}

The Indian legal system is based on the fundamental principle of $u b i$ jus ibi remedium, which means "where there is a right, there is a remedy" has been adopted in the Indian legal system. Where a litigant has a civil dispute, he can institute a civil suit in the competent civil court unless the cognizance is either expressly or implicitly barred by a statute. Section 9 of the Code of Civil Procedure primarily deals with the question of a civil court's jurisdiction to entertain a cause. It lays down that, subject to what is contained in sections $10,11,12,13,47,66,83,84,91,92,115$ of the CPC, a civil court has jurisdiction to entertain a suit of a civil nature except when its cognizance is expressly barred or barred by necessary implication. A civil court has jurisdiction to try 
a suit only if two conditions are fulfilled: firstly, the suit must be of a civil nature and, secondly, the cognizance of such a suit should not have been expressly or implicitly barred. The exclusion of the jurisdiction of a civil court is not to be readily inferred and such exclusion must be clear. Defect in the jurisdiction cannot be cured by consent of the parties, and a judgment or order issued by a court is null and void and the validity thereof can be challenged at any stage. A decree issued by a court without jurisdiction is a coram non judice. A decree issued without jurisdiction is a nullity and its invalidity could be established whenever it is sought and wherever it is sought to be enforced or relied upon, even at the stage of execution and even in collateral proceedings. Where a court has jurisdiction to decide a dispute, the same cannot be taken away or ousted by consent of the parties. An agreement to oust absolutely the jurisdiction of the court would be unlawful and void, being against public policy.

Jurisdiction of the courts is divided in the following ways.

1. Jurisdiction on the basis of the subject matter: certain courts are precluded from having jurisdiction on the basis of the subject matter. Small cause courts can try only such suits as a suit for money due on account of an oral loan or under a bond or promissory note, or a suit for work performed, etc., but it has no jurisdiction to try suits for specific performance of contracts, for dissolution of partnership, for an injunction, suits relating to immovable property or defamation.

2. On the basis of local or territorial jurisdiction: every court has its own limits, fixed by the government, beyond which it cannot exercise its jurisdiction. Thus, the district judge is in charge of the district and cannot exercise his powers beyond that district. Similarly, the civil judge (Junior Division) is in charge of the areas assigned to him. The High Court has jurisdiction over the whole territory of the state within which it is situated.

3. Pecuniary jurisdiction: there are throughout India a large number of civil courts of different grades having jurisdiction to try suits or hear appeals of different amounts or value. Some of these courts have unlimited pecuniary jurisdiction. Thus, the High Court and courts of district judges have unlimited pecuniary jurisdiction. The civil judge of a Junior Division can hear suits valuing not more than Rs.200,000 and the civil judge of the Senior Division can try suits valuing up to Rs. one million.

4. Original or appellate jurisdiction: the High Courts have only appellate jurisdiction, except in the case of writs; whereas District Courts have both original and appellate jurisdiction. Original jurisdiction only: this applies with respect to a civil judge of a Senior Division and a civil judge of a Junior Division.

\section{Role of Judges}

A judge is the presiding officer of a civil court. ${ }^{3}$ Judges use their knowledge and experience of the law to ensure that a trial is conducted in a fair and legal manner.

3 Sec. 2(8) of the CPC, 1908. 
The roles played by judges differ from case to case and court to court. Civil cases are handled differently than criminal cases. In civil cases, the judge encourages cooperation between the two sides so as to settle the case and suggests alternative ways of solving the legal problem underlying the case. In India, judges are independent from the police and the government, and make their own decisions according to the law. If a party has an objection against a judge's decision, he may appeal to a higher court. Laws are created by Parliament, and the judges are empowered to ensure that people are punished if they break those laws, but judges of the Supreme Court and sometimes judges of the High Courts also make law by way of interpretation, and also apply such law, which is law that has grown out of decisions by judges in court cases over decades and even centuries. Decisions made by judges in higher courts are recorded, and judges of lower courts use those decisions to help them make their own rulings in court cases. When judges announce a sentence on a convicted criminal, they must work within guidelines set by the legislature. This process helps to ensure that decisions are fair. In civil cases, judges play a very important role in deciding the outcome of the case as well as in deciding the amount of damages that a plaintiff is entitled to. They also manage the cases in which they are involved to ensure efficiency, and they hear appeals on the finding of liability and the amount of damages awarded. When a case is presented, the judge decides on the facts and applies the relevant law to these facts. This includes taking evidence from key witnesses involved in order to come to a final decision. There is huge responsibility on judges to ensure that both parties have equal opportunity to have their case presented. Once the judgment has been announced it is up to the judge to decide on the damages that will be awarded to the winning party. In case of injunction or any other matter the role of the judge is to decide on an appropriate resolution to the case. When a civil case takes place, there is always the question of costs that are incurred by both of the parties involved, and so another role of the judge will be, after the judgment is announced, to deal with the costs. The role of a judge does not just stop at arriving at a judgment and awarding damages, he or she also plays a very active role in the execution of the proceedings. The judge also helps the parties to settle the case not only by deciding the judgment but also by encouraging the use of alternative dispute resolution (ADR), such as negotiation, mediation and arbitration in the civil justice system. The judges who sit on the higher courts, such as the Supreme Court, interpret the law.

\section{Evidence}

Evidence is an integral part of the law of civil procedure in India. If the plaintiff wants to prove his case, he has to submit evidence in support of his claim. According to Order XVIII, rules 2 and 3 of the Code of Civil Procedure, the party having the right to begin states his case on the date fixed for the hearing of the suit and produces his evidence in support of the issues which he is bound to prove. Then the other party states his case and produces his evidence and addresses the court, generally on the whole case. 
When there are several issues, the burden of proving some of which lies on the other party, the party beginning may, at his option, either produce his evidence on those issues or reserve it by way of answer to the evidence produced by the other party.

The evidence from witnesses, according to Order XVIII, rule 4, shall be taken orally in open court in the presence and under the personal direction and superintendence of the judge. It will be given in the language of the court, ordinarily in the form of narrative and, when completed, shall be read over in the presence of the judge and the witness, and the judge shall sign it. Where the evidence has been taken down in a language different from that in which it is given, and the witness does not understand the language in which it has been taken down, the evidence so recorded shall be interpreted to him in the language in which it is given.

In non-appealable cases, and also in appealable cases, under Order XIII, rules 8 and 13 , where the evidence is not taken down in writing by the judge (or his dictation in open court or recorded mechanically in his presence), he shall be bound, as the examination of each witness proceeds, to make a memorandum of the substance of what each witness deposes, and such memorandum shall be written and signed by the judge and shall form part of the record.

Where a judge is prevented by death, transfer or other cause from concluding the trial of a suit, his successor, under Order XXXVIII, rule 15, will deal with the evidence or memorandum taken down or made as if such evidence or memorandum had been taken down or made by him and proceed with the suit from the stage at which his predecessor left.

At the trial the plaintiff has the right to begin unless the defendant admits the facts alleged by the plaintiff, and where the defendant admits only some of the facts alleged by the plaintiff, it does not give him the right to begin. Sections 101-114 of the Indian Evidence Act, 1972 deal with the burden of proof; section 102 of the Evidence Act, 1972 provides that the burden of proof lies on the party who would fail if no evidence at all were given on either side.

\section{Summary Proceedings}

Order XXXVII of the Code of Civil Procedure provides summary procedure in respect of certain suits, such as suits based on negotiable instruments or where the plaintiff seeks to recover debt or a liquidated amount. Order XXXVII, rules 1 to 7 contain the various provisions which deal with summary proceedings. Rule 1 of Order XXXVII applies to the High Courts, city civil courts, courts of small causes and other courts, in respect of which the High Court may, by notification in the Official Gazette, restrict the operation of this order only to such categories of suits as it deems proper. Order XXXVII covers within its purview certain classes of suits such as suits based on a bill of exchange, hundies (a kind of demand draft) and promissory notes; or suits in which the plaintiff seeks only to recover a debt or a liquidated demand in money payable by the defendant, with or without interest, arising from a written contract, 
or from an enactment; or from a guarantee, where the claim against the principal is in respect of a debt or a liquidated demand only.

Institution of summary suit. Order XXXVII, rules 2 and 3 provide the procedure of summary suits. The complaint in a summary suit must contain the averments mentioned in clauses (a) and (b) of sub-rule (1) besides other averments as in an ordinary complaint, and the complaint must bear the inscription mentioned in clause (c) of sub-rule (1) of this rule. The summons in summary suit must be in form No. 4 in appendix $B$ or in such form as may be prescribed from time to time. The defendant has to file an appearance within ten days of service of summons in summary suit and if the defendant does not enter such appearance, he is not entitled to defend the suit.

(a) Procedure for the appearance of the defendant.

If the defendant appears, the plaintiff has to serve on the defendant the summons for judgment under sub-rule (3) of rule 3, and thereafter under sub-rule (5) of rule 3, on such summons for judgment, the defendant can apply for leave to defend the suit. The application for leave to appear and defend must be made within ten days from the date of service of summons for judgment on the defendant while entering of appearance is mandatory under Order XXXVII, rule 3, filing of address for service and giving notice to the plaintiff or his counsel of entering appearance are mandatory. He must apply for leave to defend within ten days from the date of service of summons upon him and such leave will be granted only if the affidavit filed by the defendant discloses such as the court may deem sufficient for granting leave to the defendant to appear and defend the suit. If no leave to defend is granted, the plaintiff is entitled to a decree. In summary suit, "the trial" really begins after the court or judge grants leave to the defendant to contest the suit.

(b) Power of the court to set aside the decree.

Order XXXVII, rule 4 provides that the court may set aside the decree and stay the execution and may grant the defendant to appear and defend the suit. Thus, if a case comes within the ambit of rule 4, there is no scope to invoke section 151 of the Code of Civil Procedure for setting aside such a decree. Order XXXVII, rule 6 provides that the court may order the bill, hundi or demand notice on which the suit is founded to be forthwith deposited with an officer of the court, and may further order that all proceedings shall be stayed until the plaintiff gives security for the cost thereof. There is no bar against revision or an appeal in a decree passed in summary suit.

\section{Appellate Proceedings}

Appellate provisions. The Code of Civil Procedure provides for right to appeal and also procedure for appeal, i.e., where shall the appeal lie in civil suits. Order XLI of the Code deals with the provisions of appeal. Under Order XLIII, rule 1 no appeal can lie against a mere finding. Provisions of law governing appeals are envisaged in sections 96 to 112 and Orders XLI to XLV of the Code of Civil Procedure. Section 96 of the CPC gives right to appeal from an original decree. Section 100 of the CPC gives 
right to appeal from an appellate decree in certain cases. Section 109 of the CPC provides right to appeal to the Supreme Court in certain cases. Further, section 104 of the CPC provides right to appeal from orders as distinguished from decrees. Any party to the suit who is adversely affected by the decree or the transferee of interest of such party has been adversely affected by the decree, provided his name was entered into record of a suit, may file an appeal or an auction purchaser from an order in execution of a decree to set aside the same on the grounds of fraud or any person who is bound by the decree and the decree would operate res judicata against him. Order XLI prescribes the procedure relating to appeals from an original decree. An appeal is to be preferred in the form of a memorandum having grounds signed by the appellant or his pleader and presented to the court. Section 107 of the CPC and Order XLI, rules 23 to 29 and 33 deal with the powers of an appellate court, which include the power to pronounce the judgment, to remand a case with the direction as to what issue or issues should be tried in the case so remanded, to frame or try any issue or to determine any question of fact, which the trial court has omitted to frame, or try any issue and which appears to the court essential for the right decision, to take additional evidence, etc.

Appeal from an original decree under section 96 of the CPC. Sections 96 to 99-A of the CPC and Order XLI deal with the provisions in respect of appeals from an original decree. Section 96 confers the right to appeal against every decree passed by any court exercising original jurisdiction. No appeal lies against the decree passed by a small cause court, if the value of the subject matter does not exceed Rs.10,000 except on appeal a question of law. No appeal shall lie where a decree is passed on the basis of the consent of the parties. ${ }^{4}$ An aggrieved party can file appeal against an ex parte order under section 96(2) or seek review of a decree under Order IXVII, rule 1 or file an application under Order IX, rule 13 for setting aside the exparte decree. The right of first appeal is a matter of right where the parties have a right to be heard both on questions of law and on questions of fact. Section 97 enables the aggrieved party to appeal against the preliminary decree, but he shall be precluded from disputing its correctness in any appeal which may be preferred from the final decree if he does not appeal from the preliminary decree. All the grounds shall be set forth in the memorandum of appeal, but the appellate court in deciding the appeal need not be confined to the grounds of objections set forth in memorandum of appeal or taken by the leave of the court. Order XLI, rule 16 provides that the appellant has the right to begin hearing on the day of the hearing. The court may dismiss the appeal if the appellant does not appear on the fixed day, but the court may allow the appellant and re-admit the appeal on showing and proving sufficient cause for non-appearance. Where the appellant appears and respondent does not appear and when the appeal is called on for hearing, the appeal will be heard ex parte against the respondent. Where the ex parte decree is made the respondent may apply to the appellate court

4 Sec. 96(3) of the CPC, 1908. 
to again hear the appeal and if he satisfies the court that the notice was not duly served or that he was prevented by sufficient cause from appearing, the court may rehear the respondent against whom the ex parte decree was made.

Second appeal (appeal from an appellate decree), section 100 of the CPC. Section 100 of the CPC provides the conditions precedent for entertaining a second appeal and the specific manner of its disposal. According to section 100 of the CPC, an appeal shall lie to the High Court from every decree passed in appeal by any court subordinate to the High Court, if the High Court is satisfied that the case involves a substantial question of law.

Appeals to the Supreme Court under section 109 of the CPC. Subject to the provisions in Chapter IV of Part V of the Constitution, an appeal shall lie to the Supreme Court from a High Court, if the High Court certifies:

(i) that the case involves a substantial question of law of general importance; and

(ii) that in the opinion of the High Court the said question needs to be decided by the Supreme Court. Art. 136 of the Constitution provides the provisions for special leave to appeal to the Supreme Court from any judgment order in any matter from any court or tribunal.

\section{Class Actions}

Definition. A class/collective action is a lawsuit in which a single person or small group of individuals represent the interests of a larger group before the court. A class action is also a procedural instrument which enables one or more claimants to file and prosecute litigation on behalf of a larger group, class or entities with common rights and grievances.

Class action in the CPC. Order I, rule 8 of the CPC is quite clear so far as class actions are concerned. The general rule is that all persons interested in a suit ought to be made parties, but there is an exception to this general rule where one or more persons may sue or defend on behalf of all having the same interest in the suit. Such suits are called representative suits and are governed by Order I, rule 8 of the CPC, which provides where there are numerous persons having the same interest in one suit, one or more of such persons may, with the permission of the court, sue or be sued, or may defend, in such suit, on behalf of one or for the benefit of all persons so interested. But the court shall in such case give, at the plaintiff's expense, notice of the institution of the suit to all such persons either by personal service or, where from the number of persons or any other cause such service is not reasonably practicable, by public advertisement, as the court in each case may direct. Further, any such person on whose behalf or for whose benefit a suit is instituted or defended under sub-rule (1) may apply to the court to be made a party to such suit.

The object of this rule is to afford convenience in suits where there is community of interest, among a large number of persons, so that a few should be allowed to 
represent the whole, in order to save trouble and expense and to ensure a convenient trial of questions to which a large body of persons are interested, while avoiding multiplicity of suits and harassment to parties.

A decree passed in a representative suit operates as res judicata. In a subsequent suit against such interested persons although they may not have been added as parties to the suit, Explanation VI to section 11 provides that where persons litigate bona fide in respect of a public right or a private right claimed in common for themselves and others, all persons interested in such right shall, for the purposes of this section, be deemed to claim under the persons so litigating.

Writ jurisdiction. In writ jurisdiction, representative actions or actions brought in the public interest via public interest litigation (PIL) have gained much popularity and are widely used to the Supreme Court for the enforcement of fundamental rights under Art. 32 of the Constitution, or to the High Courts for the enforcement of fundamental rights or any other legal right under Art. 226 of the Constitution of India.

\section{Costs and Funding}

Costs. "Cost of any proceedings or cost incidental to any proceedings" means the cost of any proceedings such as may be determined at the conclusion of the hearing and not payable in advance or to be incurred in future by a party. Where a court has jurisdiction to deal with the question of cost, no separate suit will lie to recover costs, but where it has no jurisdiction to order the costs and costs are incurred, cost may be made the subject of consideration as to damages in a subsequent suit. The person who lacks sufficient funds to pay court costs, procedural costs and counsel fees will be entitled to free legal aid which includes mostly judicial fees and costs, postage stamps, the fees of counsel and experts, and the compensation of the interpreter or translator for the cost of instituting execution proceedings, the deposits required by law to lodge appeals and the fees owed to notaries or registrars arising from the performance of registrations, declarations. An appeal lies on cost only in a few cases.

Kinds of costs:

(a) general costs (section 35, CPC);

(b) miscellaneous costs (Order XX-A, CPC);

(c) compensatory costs for false and vexatious claims (section 35-A, CPC);

(d) costs for causing delay (section 35-B, CPC).

General costs. Section 35, CPC deals with general costs. It aims to secure the litigant the expenses incurred by him in the litigation. The courts have been given the discretion to decide the cost on the basis of legal principle.

Miscellaneous costs. Order XX-A, CPC empowers the court to award costs in respect of certain expenses incurred in giving notices, typing charges, producing witnesses, inspection of records, etc.

Compensatory costs. Section 35-A, CPC provides the provisions for compensatory costs. Under this section, if the court finds that litigation is inspired by vexatious motive 
or false claims, it can indemnify the aggrieved party. The maximum amount that can be awarded by the court is Rs.3,000. This section applies only to suit and not to appeals or to revisions; however, an order awarding compensatory cost is appealable.

Costs for causing delay. Section 35-B, CPC is added by the Amendment Act of 1976. This section enables the courts to impose compensatory costs on the parties who are responsible for causing delay at any stage of the litigation.

Other miscellaneous provisions relating to costs in the CPC are:

1. Order XI, rule 3 - cost of interrogatories.

2. Order XII, rule 2 - costs of proving any document.

3. Order XXI, rule 72(3) - cost of setting aside the sale where decree holder purchases property without the permission of the court.

4. Order XXXII, rule 1(3) - costs relating to appointment of guardian ad liteum.

5. Order XXXIII, rules 10,11 and 16 - costs relating to suit by indigent persons.

6. Order XXXV, rule 3 - costs relating to inter pleader suit.

\section{Enforcement of Proceedings}

Execution of decree. The execution is the last stage of any litigation. In India, the term "execution" has not been defined in the Code of Civil Procedure. Under Indian law, execution of decrees, whether foreign or domestic, is governed by the provisions of the Code of Civil Procedure. A decree or order will be executed by the court which has passed the judgment. In exceptional circumstances, the judgment will be implemented by another court having the competency in that regard. The Code of Civil Procedure contains elaborate and exhaustive provisions for dealing with the enforcement or execution of the decree. The numerous rules of Order XXI of the CPC take care of different situations providing effective remedies not only to judgment debtors and decree holders but also to claimant objectors, as the case may be. Provisions of the CPC relating to execution of decree and order are made applicable to both appeal and suit. The following persons may file an application for execution:

(a) decree holder, according to Order XXI, rule 10;

(b) legal representative of decree holder, as per section 146 of the Code;

(c) any person claiming under the decree holder, as per section 146 of the Code;

(d) transferee of decree holder to whom the decree must have been transferred by an assignment in writing or by operation of law.

Procedure of execution. The procedure in execution or mode for execution is provided in sections 51 to 54 of the CPC. Besides these sections, the process for execution is provided under Order XXI, rules 24 and 25 . There are various modes of execution of decree in the CPC. A decree may be enforced by delivery of any property specified in the decree, by attachment and sale or by sale without attachment of the property, or by arrest and detention in civil imprisonment, or by appointing a receiver, or by effecting partition, or any such manner which the nature of relief may require. The $\mathrm{CPC}$ recognizes the right of the decree holder to attach the property of the judgment 
debtor in execution proceedings and lays down the procedure to effect attachment. Sections 60 to 64 and rules 41 to 57 of Order XXI of the CPC deal with the subject of attachment of property. Section 60 specifies properties which are not liable to be attached or sold. Whereas section 46 of the CPC provides for issuance of "precept." A decree may be executed by attachment and sale or sale without attachment of any property. Sections 65 to 73 of the CPC and rules 64 to 94 of Order XXI of the CPC deal with the subject relating to sale of movable and immovable property. Section 52 of the CPC provides the enforcement of a decree against legal representative of the judgment debtor. Section 54 deals with a case where, though the civil court has the power to pass a decree, yet it is not competent to execute the same. The period of limitation for the execution of a decree other than a decree granting a mandatory injunction is twelve years from the date of the decree. ${ }^{5}$ The limitation period for the execution of a decree for mandatory injunction is three years from the date of the decree. ${ }^{6}$ It is the proceedings by which the decree holder seeks to reach money or property of the judgment debtor in the hands of a third party (debtor of judgment debtor). Women, judicial officers, the parties, their pleaders, members of legislative bodies, minors or a judgment debtor where the decretal amount does not exceed Rs.2,000, these persons cannot be arrested and detained in civil imprisonment.

Execution of a foreign decree. Under Indian law there are two ways of getting a foreign judgment enforced. Firstly, by filing an execution petition under section $44 \mathrm{~A}$ of the CPC and secondly by filing a suit against the foreign decree. Under section 44A of the CPC, the decree of the superior court of any reciprocating territory is executable as a decree passed by the domestic court. The reciprocating territory is notified by the central government in the Official Gazette. In case the decree pertains to a country which is not a reciprocating territory then a fresh suit will have to be filed in India on the basis of such a decree or judgment, which may be construed as a cause of action for the said suit and in such suit the said decree will be treated as another piece of evidence against the defendant. Section 13 of the CPC specifies certain exceptions under which the foreign judgment becomes inconclusive and is therefore not executable or enforceable in India. They are the following circumstances:

(a) where it has not been pronounced by a court of competent jurisdiction;

(b) where it has not been given on the merits of the case;

(c) where it appears on the face of the proceedings to be founded on an incorrect view of international law or a refusal to recognize the law of India in cases in which such law is applicable;

(d) where the proceedings in which judgment was obtained are opposed to natural justice;

(e) where it has been obtained by fraud;

(f) where it sustains a claim founded on a breach of any law in force in India.

\footnotetext{
Limitation Act, 1963, Art. 136.

6 Limitation Act, 1963, Art. 133.
} 


\section{Arbitration and ADR}

Arbitration. Arbitration is one of the modes of ADR prescribed by section 89 of the CPC. Prior to incorporation of section 89 in the Code of Civil Procedure the parties to litigation, with mutual consent, could take recourse to arbitration as a mode of resolution of their dispute under the Arbitration and Conciliation Act, 1996. This Act, however, did not contemplate a situation as in section 89 of the CPC, where the court asks the parties to choose any ADR mechanism and the parties choose arbitration as their option. Section 89 of the CPC now provides for reference of a dispute in a sub judice matter to arbitration. The provisions of the Arbitration and Conciliation Act, 1996 shall apply to the proceedings provided as though the proceedings for arbitration were referred for settlement under the provisions of that Act. Arbitration commences with the consent of all the parties. Arbitration effectively puts an end to the dispute. Unlike conciliators, arbitrators do not need the consent of parties in order to issue an award that legally binds the parties. If reference is made to arbitration under section 89 of the CPC, the Arbitration and Conciliation Act, 1996 would apply only from the stage after reference and not before the stage of reference when options under section 89 of the CPC are given by the court and chosen by the parties. The arbitration process results in an award, which is enforceable as the decree of civil court, and the parties are bound by the same. Thus, the decision of the forums specified under section 89 shall be as effective, having the same binding effect as court orders or decrees and arrived at a relatively cheaper cost and within a short span of time. The object of the Act is to consolidate and amend the law relating to domestic arbitration, international commercial arbitration and enforcement of foreign arbitral awards.

ADR (alternative dispute resolution) system. ADR is formulated with the purpose of reducing the burden of the already burdened system and render expeditious justice. Section 89 of the Code of Civil Procedure was introduced with the purpose of amicable, peaceful and mutual settlement between parties without intervention of the court. At the commencement of the Code of Civil Procedure, a provision was provided for alternate dispute resolution, but the same was repealed by the enactment of the Arbitration Act, 1940 under section 49 and Schedule 10 . Section 89 of the CPC came into being in its current form on account of the enforcement of the CPC Amendment Act, 1999 with effect from 1 July 2002. Later on, new alternatives were added which were not restricted to arbitration only. Section 89 along with rules $1 \mathrm{~A}, 1 \mathrm{~B}$ and $1 \mathrm{C}$ of Order $\mathrm{X}$ of the first schedule have been implemented by sections 7 and 20 of the CPC Amendment Act, 1999 and cover the ambit of law related to alternate dispute resolution. The clauses under Order $\mathrm{X}$ are specified to ensure proper exercise of jurisdiction by the court. Sub-section (1) refers to the different mediums for alternate resolution and sub-section (2) refers to various Acts in relation to the mentioned alternate resolutions. According to section 89 of the CPC where it appears to the court that there exist elements of a settlement which may be acceptable to the parties, the court shall formulate the terms of settlement and 
give them to the parties for their observations and after receiving the observation of the parties, the court may reformulate the terms of a possible settlement and refer the same for arbitration; conciliation; judicial settlement including settlement through Lok Adalat (people's court); or mediation. For arbitration or conciliation, the provisions of the Arbitration and Conciliation Act, 1996 shall apply and the rules can be made under Part X of the CPC for determining the procedure for opting for "conciliation" and up to the stage of reference to conciliation. Similarly in case where the dispute is referred to Lok Adalat the provisions of section 20(1) of the Legal Services Authority Act, 1987 shall apply and for mediation, the court shall effect a compromise between the parties and shall follow such procedure as may be prescribed. While judicial settlement through Lok Adalat, as under sections 89(1)(c) and 89(2)(c), could only be in terms of Legal Services Authority Act, 1989.

Cases for which ADR is effective. All other suits and cases of a civil nature, in particular the following categories of cases (whether pending in civil courts or other special Tribunals/Forums), are normally suitable for ADR process:

(i) all cases relating to trade, commerce and contracts;

(ii) all cases arising from strained or soured relationships;

(iii) all cases where there is a need for continuation of the pre-existing relationship in spite of the dispute;

(iv) all cases relating to tortious liability, and

(v) all consumer disputes.

Thus it is effective to deal with the problem of the enormous arrears of cases, appeals, procedural shackles and the adversarial system which results in the failure of justice.

\section{Role of Academia}

The role of academia in India has always been significant in the evolution and development of the present structure of the Code of Civil Procedure. Before the First Code of Civil Procedure of 1859, there were Acts and Regulations which regulated civil procedure of the mofussil courts. The various Law Commissions which were set up to codify the laws in India always took the assistance of the various jurists of India. A large number of scholars and writers made contributions to the development of the civil procedural law in India. Among them were D.F. Mulla, Supto Sarkar \& Manohar, Palmtop, B.M. Prasad \& Manish M. Valechha, Woodroffe \& Ameer Ali, P.S. Narayana, Suranjan Chakraverty, Bholeshwar Nath \& M.M.L. Singhal, K. Padmanabhan Nair and N. Ajith, A.N. Saha, and others.

\section{Statistics}

Two Law Commissions of India recommended increasing the proportional strength of judges to fifty per million of the population. The current sanctioned numerical strength, however, of the subordinate judiciary is 20,214 judges, while that of the 
twenty-four High Courts is 1,066; and the backlog of cases has remained abnormally high at 31 million.

As against the sanctioned strength of the subordinate strength, there are more than 4,600 vacancies for judges in the subordinate judiciary, which is more than 23 per cent of the strength. There are at present $21,805,869$ cases pending before the courts.

The condition in the High Courts is worse with almost 52 per cent (549) of the posts of the judges lying vacant. The Supreme Court too has six vacancies on a sanctioned strength of 31. The Law Commission of India in its $20^{\text {th }}$ Report found that at the current rate of disposal, High Courts required at least an additional 58 judges to break even and an additional 942 judges to clear the backlog. It may be pointed out that the current judge-population ratio stands at 17 on its sanctioned strength, i.e., one judge per over 58,800 of the population.

\section{Comparative Observations}

The Indian civil justice system resembles its common law counterparts. It features a coordinate, pyramid structure of judicial authority, emphasizes formal procedural justice dominated by litigants of equal status engaged in adversarial processes, and provides binding, win-lose remedies. Emphasis is placed on the law laid down by the Supreme Court. India follows the doctrine of precedent as against the importance of law enacted by Parliament, which prevails in civil law countries.

The practical application of this system in India has achieved mixed results. Some observers have recently emphasized the positive role played by a strong Indian judiciary in increasing the accountability of democratically elected people. Yet, others believe the adversarial procedural justice system in India has failed from its inception. As India celebrates its seventieth year of independence, and as it pursues economic liberalization efforts, it is time to assess its civil justice process and to facilitate the design of long-needed reforms. Based on the views of a broad array of legal experts in India, the judiciary in India is the sole arbiter of the Constitution, the authoritative interpreter of the will of the people, and the protector of the freedom and liberty of the people.' The Indian civil justice system features a civil service of court administrators, an independent judiciary, a rich supply of professional legal talent and a modern procedural code. However, the system also exhibits a general failure to manage effectively the dispute resolution processes of a democratic, socially diverse and newly market-oriented society. Specifically, inefficient court administration systems, excessive judicial passivity in an adversarial legal process, and severely limited alternatives to a protracted and discontinuous full trial frustrate the very purpose of justice. Whatever may be one's position, India has adopted the adversarial procedural system. As against inquisitorial proceedings, India follows adversarial proceedings. In civil law countries, in a typical inquisitorial proceeding, the trial is dominated by the presiding judge,

\footnotetext{
7 H.R. Khanna J. in ADM Jabalpur v. Shivakant Shukla, AIR 1976 SC 1207.
} 
who determines the order in which evidence is taken and who evaluates the content of the gathered evidence. In those proceedings, the court determines the credibility and relative weight of each piece of evidence without being constrained by strict rules in that respect. By contrast, in a typical adversarial system, the case is organized and the facts are developed by the sole initiative of the parties. The process develops through the efforts of the litigants before a passive decision maker who reaches a decision on the sole basis of the evidence and motions presented by the litigants. As the adversarial system has been so established in the judicial system of India, it is now, if not impossible, most difficult to adopt an inquisitorial system howsoever it may be beneficial to the people of India.

\section{Cultural Observations}

India is a country of multiple cultural and religious traditions in which there is a complete unity in diversity. Culture and religion have no influence on civil procedure nor does the latter have any influence on the former. India as a whole is a secular country.

\section{International Matters and BRICS Cooperation in Civil Procedure Perspectives}

In India, there is no statute relating to the matter of conflict of laws. Many provisions relating to private international law have been incorporated in the Code of Civil Procedure. For example, section 13 of the CPC lays down that, with some exceptions, a foreign judgment shall be conclusive as to any matter thereby directly adjudicated upon between the same parties or between parties under whom they or any of them claim in litigation. Similarly, section 44-A deals with the provisions relating to the execution of a foreign judgment, i.e., foreign judgments may be enforced by a suit. They may also be enforced by proceedings in execution in certain specified cases which are mentioned in section 44A of the CPC. Besides this aspect, international cooperation in the field can be in matters relating to summons and to some judicial matters.

\section{Conclusion}

India is a huge country geographically and the second largest in the world by population. The problems it faces are great as well and they are multifaceted. The country, at present, has a growing economy and is gradually becoming a highly industrialized nation. And along with this economic development, a multitude of commercial and industrial development problems, among many others, appear. Also appearing is the increase in litigation of many kinds that is seriously affecting the law relating to civil procedure. Civil procedural law will have to adapt to the needs of the time, and for this to occur better and suitable provisions from other countries will need to be borrowed. 


\section{References}

Agrawal K.B. Civil Procedure in India (Alphen aan den Rijn: Kluwer Law International, 2012).

Babel B.L. A Guide to Civil Practice (Lucknow: Eastern Book Company, 2013).

Jaibhave J.D. Case and Material on Civil Procedure Code with Practice \& Procedure (Lucknow: Eastern Book Company, 2008).

Jain M.P. The Code of Civil Procedure, 1908 (Lucknow: EBC Pub., 2011).

Jois R. Seeds of Modern Public Law in Ancient Indian Jurisprudence (Lucknow: Eastern Book Company, 1990).

Mishra A. Civil Procedure Code, 1908 (New Delhi: Upkar Pub., 2010).

Moitra A.C. \& Monir M. Law of Estoppel \& Res-Judicata ( $4^{\text {th }}$ ed., Delhi: Universal Law House, 2015).

Mulla D.F. The Key to Indian Practice - A Summary of the Code of Civil Procedure (11 ${ }^{\text {th }}$ ed., Lucknow: EBC Pub., 2015).

Ray S. Textbook on the Code of Civil Procedure ( $3^{\text {rd }}$ ed., Delhi: Universal Law House, 2015).

Sarkar S. \& Manohar V.R. The Code of Civil Procedure, $1908\left(11^{\text {th }}\right.$ ed., Lucknow: EBC Pub., 2006).

Sharma S.D. Administration of Justice in Ancient India (New Delhi: Harman Publishing House, 1988).

Shukla V.N. The Constitution of India (M.P. Singh, ed., $9^{\text {th }}$ ed., Lucknow: Eastern Book Company, 1994).

Singh A. Law of Arbitration \& Conciliation and Alternative Dispute Resolution System (10 ${ }^{\text {th }}$ ed., Lucknow: Eastern Book Company, 2013).

Vyasa V. \& Bhanot S.D. Ancient India (Delhi: Royal Publications, 1995).

Woodroffe J.G. \& Ameer Ali M.S. Commentary on Code of Civil Procedure Act, 1908 (6 ${ }^{\text {th }}$ ed., Delhi: Delhi Law House, 2015).

\section{Information about the authors}

Krishna Agrawal (Jaipur, India) - Director, Indian Institute of Comparative Law, Former Dean, Faculty of Law, University of Rajasthan (JLN Marg, Jaipur, 302004, India; e-mail: kbagrawal09@rediffmail.com).

Neha Dixit (Jaipur, India) - Assistant Professor of Law, University of Rajasthan (JLN Marg, Jaipur, 302004, India; e-mail: jdneha@yahoo.com). 